\title{
Pengaruh Kompetensi Guru dan Implementasi Kurikulum Asing Terhadap Kinerja Guru di Sekolah Internasional Jakarta Utara
}

\author{
Domina Elfrida \\ Universitas Negeri Jakarta \\ dominael06@gmail.com
}

\begin{abstract}
This study aims to investigate the influence of teachers' competence and implementation of international curriculum on teachers' performance in North Jakarta International Schools. This research was conducted based on the problem that there were still many teachers who do not have good performance. This research uses quantitative study with a survey and interviews to collect data from the respondents. This study employs path analysis technique to test the bypothesis. The sample in this study is 55 teachers in North Jakarta International Schools which is taken by using simple random sampling. The results show that (1) teachers' competence has a positive and effect on teachers' performance, (2) the implementation of international curriculum has a positive effect on teachers' performance, and (3) teachers' competence has a positive effect on the implementation of international curriculum.
\end{abstract}

Keywords : Implementation of International Curriculum; Teachers' Performance;

Teachers' Competence; International Schools.

Abstrak : Penelitian ini bertujuan untuk mengetahui pengaruh kompetensi guru dan implementasi kurikulum asing terhadap kinerja guru di Sekolah Internasional Jakarta Utara. Penelitian ini dilakukan dengan didasari permasalahan bahwa masih banyak guru yang belum memiliki kinerja yang baik. Penelitian ini adalah penelitian kuantitatif dengan menggunakan metode survey dan wawancara terstruktur untuk mengumpulkan data dari responden. Sedangkan teknik analisis data yang digunakan untuk menjawab hipotesis penelitian ini adalah statistik dengan model analisis jalur (path analysis). Adapun sampel dalam penelitian ini adalah guru di sekolah Internasional Jakarta Utara sebanyak 55 orang yang diambil dengan menggunakan simple random sampling. Hasil penelitian menununjukkan bahwa (1) kompetensi guru berpengaruh positif terhadap kinerja guru, (2) implementasi kurikulum asing berpengaruh positif terhadap kinerja guru, dan (3) kompetensi guru berpengaruh positif terhadap implementasi kurikulum asing.

Kata Kunci : Implementasi Kurikulum Asing; Kinerja Guru; Kompetensi Guru; Sekolah Internasional.

\section{Pendahuluan}

Maju dan berkembangnya suatu bangsa sangatlah ditentukan oleh kualitas pendidikan bangsa tersebut. "The success or failure of any nation depends largely on the quality of its educational system" (Olaleye \& Oluremi, 2013). Perkembangan zaman dan tuntutan globalisasi akan memunculkan iklim persaingan yang semakin ketat. Untuk itu dibutuhkan pengetahuan dan wawasan yang luas agar dapat memenangkan persaingan yaitu dengan cara memajukan pendidikan.

Bangsa Indonesia merupakan salah satu bangsa yang tidak akan berhenti melakukan pembangunan dalam sektor pendidikan dengan maksud agar kualitas SDM yang dimiliki mampu bersaing secara global, sebagaimana yang tercantum dalam Undang-Undang Nomor 20 Tahun 2003 tentang Sistem Pendidikan Nasional. Maka dari itu, perlu diterapkan satu sistem yang berorientasi pada keberhasilan pendidikan. 
Salah satu sumber daya sekolah yang sangat berperan penting dalam meningkatkan kualitas SDM di sekolah adalah tenaga pengajar atau guru. "Consequently, improving the quality of teacher performance is a viable and important strategy for improving student achievement" (Olaleye \& Oluremi, 2013). Kinerja guru akan sangat berpengaruh dalam keberhasilan siswa.

Kinerja dapat didefinisikan sebagai tingkat pencapaian seseorang secara keseluruhan selama periode tertentu (Moeheriono, 2009). Menurut UndangUndang Republik Indonesia Nomor 14 Tahun 2005 tentang Guru dan Dosen, "guru adalah pendidik profesional dengan tugas utama mendidik, mengajar, membimbing, mengarahkan, melatih, menilai, dan mengevaluasi peserta didik pada pendidikan usia dini, pendidikan dasar, dan pendidikan menengah". Tugas utama guru tersebut akan terlaksana dengan baik apabila guru mempunyai kinerja yang baik. Kinerja guru ini merupakan input yang paling penting dalam penyelenggaraan pendidikan, namun fakta menunjukkan bahwa kinerja guru masih belum optimal.

Berdasarkan Education Index yang dikeluarkan oleh Human Development Reports pada 2017, Indonesia ada di posisi ketujuh di ASEAN dengan skor 0,622. Ini artinya Indeks pendidikan di Indonesia masih rendah. Bahkan menurut laporan PISA (Programme for International Student Assessment) yaitu program yang mengurutkan kualitas sistem pendidikan di 72 negara, pada tahun 2015 Indonesia menduduki peringkat 62 yang artinya pendidikan di Indonesia masih rendah. Apabila dikaji permasalahan yang ada, akan sulit untuk menemukan ujung pangkal permasalahannya. Namun sangat diyakini bahwa kinerja guru memiliki andil terpenting.

Banyak faktor yang dapat mempengaruhi kinerja guru. Dari beberapa faktor yang ada, kompetensi guru diduga memiliki pengaruh yang sangat kuat terhadap kinerja guru sehingga dijadikan bahan kajian dalam penelitian ini. Dalam Permendiknas No.16 Tahun 2007 tentang Standar Kualifikasi Akademik dan Kompetensi Guru dikatakan bahwa kompetensi guru akan terintegrasi dalam kinerja guru.

Disamping itu, kurikulum yang digunakan suatu sekolah juga diyakini sangat mempengaruhi kinerja guru. Sebagaimana dinyatakan dalam UU No. 20 tahun 2003 tentang Sistem Pendidikan Nasional bahwa pengembangan kurikulum dilakukan dengan mengacu pada standar pendidikan nasional untuk mewujudkan tujuan pendidikan nasional. Tujuan pendidikan nasional akan tercapai didukung oleh kinerja guru yang baik dengan kompetensi guru yang baik didukung oleh kurikulum yang baik.

Produktivitas seorang guru dapat dilihat melalui unjuk kerja dalam aktivitas belajar mengajar yang dilakukan, dan inilah yang biasa disebut dengan kinerja. Menurut Obilade dalam Adeyemi (2011) 'teachers' job performance could be described as the duties performed by a teacher at a particular period in the school system in 
achieving organizational goals". Kinerja adalah tingkat pencapaian hasil atas pelaksanaan tugas tertentu dalam rangka pencapaian tujuan organisasi. (Payman J. Simanjuntak, 2005). "Jobs performance is formally defined as the value of the set of employee behaviors that contribute, either positively or negatively, to organizational goal accomplishment" (Colquitt et al, 2011).

Dari beberapa pendapat mengenai pengertian kinerja tersebut diatas dapat disimpulkan bahwa kinerja merupakan hasil ataupun target yang dicapai melalui tindakan ataupun perbuatan yang dilakukan sesuai dengan tujuan pendidikan yang ingin dicapai.

Menurut Uno dan Lamatenggo dalam Koswara dan Rasto (2016), kinerja guru dapat diukur melalui lima indikator yaitu: kualitas kerja, kecepatan/ketetapan kerja, inisiatif kerja, kemampuan kerja, dan komunikasi.

Fathurrochman, I. (2017) menyatakan bahwa kompetensi adalah kemampuan yang dimiliki seseorang akibat dari pendidikan maupun pelatihan, atau pengalaman belajar informal tertentu yang didapat, sehingga menyebabkan seseorang dapat melaksanakan tugas tertentu dengan memuaskan (Payong, 2011). Wibowo (2007) menyatakan kompetensi adalah suatu kemampuan untuk melaksanakan atau melakukan suatu pekerjaan yang dilandasi atas keterampilan dan pengetahuan serta didukung oleh sikap kerja yang dituntut oleh pekerjaan tersebut. Menurut Keputusan Menteri Pendidikan Nasional No. 045/U/2002 tentang Kurikulum Inti Pendidikan Tinggi, kompetensi diartikan sebagai seperangkat tindakan cerdas dan penuh tanggung jawab yang dimiliki seseorang sebagai syarat untuk dianggap mampu oleh masyarakat dalam melaksanakan tugas sesuai dengan pekerjaan tertentu.

Dari beberapa pendapat diatas dapat dikatakan bahwa kompetensi merupakan karakteristik yang menggambarkan motif ataupun karakteristik pribadi, konsep diri, nilai, pengetahuan ataupun keahlian seseorang dalam berkinerja di tempat kerja.

Pada Peraturan Pemerintah RI No. 19 Tahun 2005 tentang Standar Nasional Pendidikan, selain mempersyaratkan kualifikasi akademik bagi seorang guru, guru juga harus memiliki kompetensi sebagai agen pembelajaran pada jenjang pendidikan anak usia dini, dasar dan menengah. Dalam UU No.14 Tahun 2005 tentang Guru dan Dosen menyatakan bahwa, kualifikasi akademik ini harus dibuktikan melalui penguasaan guru terhadap empat kompetensi utama, yaitu kompetensi pedagogik, kompetensi kepribadian, kompetensi profesional, dan kompetensi sosial. Hal ini diperjelas dalam Peraturan Pemerintah No.19 Tahun 2005 tentang Standar Nasional Pendidikan.

Menurut Koswara dan Rasto (2016), kompetensi guru dapat diukur melalui :

1) Pengelolaan pembelajaran, berkaitan dengan kemampuan guru dalam mengurutkan tujuan pembelajaran secara sistematis, penyesuaian media 
pembelajaran dengan materi yang disampaikan, penyesuaian pemanfaatan Teknologi Informasi dan Komunikasi sebagai sumber belajar, dan kemampuan guru untuk mengaktualisasikan berbagai potensi yang dimiliki siswa (Usman, 2011).

2) Penguasaan keilmuan, berkaitan dengan keilmuan guru dalam penyesuaian materi pelajaran dengan kompetensi inti dan kompetensi dasar, penggunaan teknik mengelola proses belajar mengajar di kelas, dan penguasaan landasan dan wawasan kependidikan dan keguruan (Mulyasa, 2007).

3) Sikap atau kepribadian, berkaitan dengan kepribadian guru dengan menampilkan diri sebagai pribadi yang jujur, berakhlak mulia, dan teladan bagi peserta didik dan masyarakat, menunjukan etos kerja, tanggungjawab yang tinggi, rasa bangga menjadi guru dan rasa percaya diri, dan menjunjung tinggi kode etik profesi guru (Olim, 2013).

4) Interaksi sosial, berkaitan dengan interaksi guru dengan siswa baik selama di sekolah maupun di luar sekolah, berinteraksi dengan sesama rekan kerja, berinteraksi dengan orang tua/wali siswa, dan berinteraksi dengan masyarakat lingkungan sekitar (Spencer \& Spencer, 1993); (Olim, 2013).

Terdapat beberapa jenis kurikulum asing yang diterapkan di sekolahsekolah di Indonesia, salah satunya adalah kurikulum Cambridge International. Kurikulum yang berasal dari Inggris ini disebut Cambridge Assessment International Education, atau disingkat menjadi Cambridge International pada tahun 2017. Kurikulum inilah yang paling banyak digunakan di sekolah Internasional.

Hal yang paling diperhatikan dalam penerapan kurikulum Cambridge adalah pemahaman, pengetahuan dan keterampilan siswa berpikir kritis yang melibatkan strategi mental, dan pembelajaran berbasis masalah serta menggunakan pendekatan belajar student center yaitu berpusat pada peserta didik yang bertujuan untuk membuat siswa aktif dalam pembelajaran. Program pendidikan Cambridge terdiri dari empat kualifikasi, yaitu: Cambridge Primary untuk anak usia 5-11 tahun, Cambridge Lower Secondary untuk usia 11-14 tahun, Cambridge Upper Secondary untuk usia 14-16 tahun, dan Cambridge advanced untuk usia 16-19 tahun (Cambridge Assesment International Education, 2019).

Melalui pembelajaran dengan kurikulum Cambridge, baik guru maupun siswa akan mempunyai lima kebiasaan belajar. Sebagaimana yang dikutip dari Cambridge Assesment International Education (2019), lima kebiasaan tersebut digambarkan seperti berikut : 


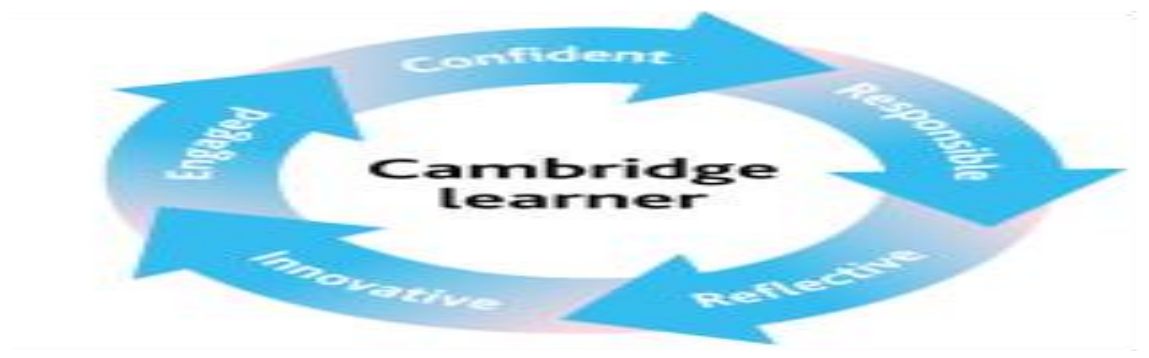

Gambar 1.

Cambridge learner attributes: confident, responsible, reflective, innovative and engaged

Implementasi kurikulum asing merupakan penerapan kurikulum dari luar negeri atau kurikulum internasional yang diadopsi maupun diadaptasi di Indonesia dengan melalui tahapan perencanaan, pelaksanaan, dan evaluasi.

\section{Metode Penelitian}

Penelitian ini menggunakan metode kuantitatif dengan pengumpulan data yang dilakukan melalui kuesioner yang dibagikan kepada berbagai responden. Studi kuantitatif adalah cara menghitung data melalui penerapan metode statistik dan analisis dan hasil analisis mewakili angka-angka yang selanjutnya menjelaskan tujuan dari masalah penelitian tertentu. Metode survei dan wawancara digunakan untuk mengumpulkan data kinerja guru, kompetensi guru, dan implementasi kurikulum asing di sekolah Internasional Jakarta Utara.

Sedangkan teknik analisis data yang digunakan untuk menjawab hipotesis penelitian ini adalah statistik dengan model analisis jalur (path analysis). Model hipotetik pengaruh antar variabel penelitian disajikan dalam gambar model berikut ini.

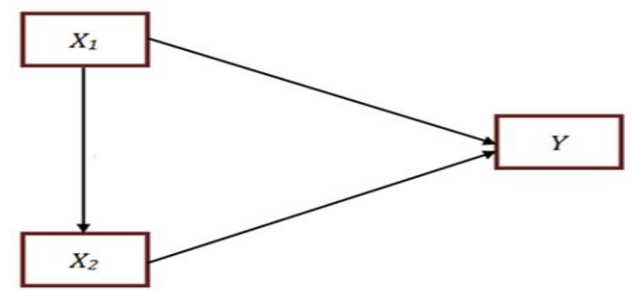

Gambar 2.

\section{Model Hipotetik antar variable penelitian}

Instrumen untuk pengukuran variabel diadopsi dari penelitian sebelumnya. Teknik analisis data yang dilakukan adalah secara deskriptif dan analisis inferensial (uji hipotesis). Penggunaan analisis data deskriptif digunakan untuk menggambarkan keadaan data masing-masing variabel yaitu, skor terendah, skor tertinggi, skor rata-rata, skor rata-rata median, modus, standar 
deviasi, varians, distribusi frekuensi dan histogram. Sedangkan analisis inferensial (uji hipotesis) digunakan untuk menguji hipotesis penelitian melalui analisis jalur (path analysis). Semua pengujian hipotesis dengan menggunakan $\alpha$ $=0,05$. Sebelum pengujian hipotesis, terlebih dahulu dilakukan pengujian 1) Uji normalitas dengan menggunakan Uji Liliefors dan 2) Uji signifikansi dan linieritas regresi dengan menggunakan Uji-F.

\section{Hasil Penelitian dan Pembahasan}

Penelitian ini mengadopsi Analisis Statistical Package for Social Sciences (SPSS) dan uji reliabilitas. Adapun sampel dalam penelitian ini adalah guru di sekolah SPK Jakarta Utara sebanyak 55 orang yang diambil dengan menggunakan simple random sampling.

\section{1) Pengaruh Kompetensi Guru terhadap Kinerja Guru}

Setelah dilakukan uji pengaruh X1 (kompetensi guru) terhadap X3 (kinerja guru) di Sekolah Internasional Jakarta Utara, maka dilakukan uji statistik dengan menggunakan Statistical Package for Social Sciences (SPSS) dan uji reliabilitas, maka diperoleh hasil sebagaimana table berikut berikut ini :

\begin{tabular}{|c|c|c|c|}
\hline \multicolumn{4}{|c|}{ Descriptive Statistics } \\
\hline & Mean & Std. Deviation & $\mathrm{N}$ \\
\hline Kinerja (X3) & 119,0545 & 15,77318 & 55 \\
\hline Kompetensi (X1) & 144,8727 & 20,83183 & 55 \\
\hline
\end{tabular}

Tabel 1.

Deskripsi statistik variabel kinerja (X3) dan kompetensi (X1)

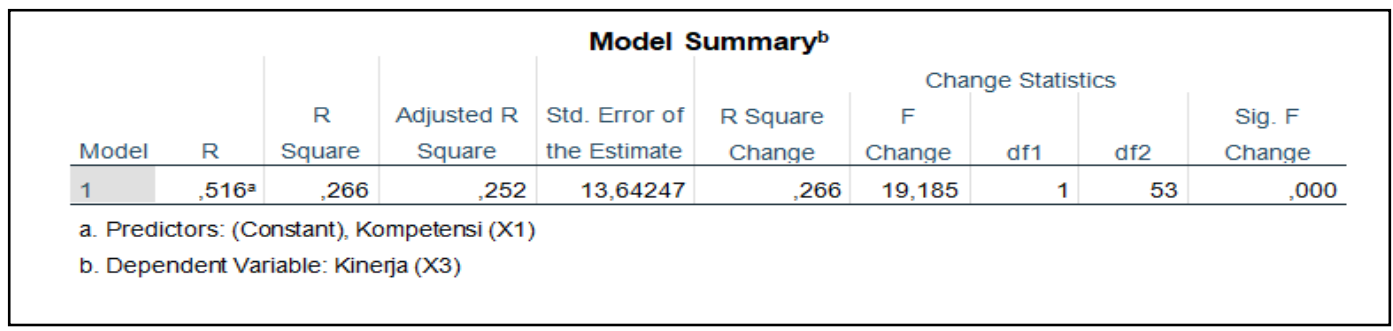

Tabel 2.

Model Summary variabel kinerja(X3) dan kompetensi (X1) 


\begin{tabular}{|c|c|c|c|}
\hline \multicolumn{4}{|c|}{ Correlations } \\
\hline & & Kineria $(\times 3)$ & Kompetensi ( $\times 1)$ \\
\hline \multirow[t]{2}{*}{ Pearson Correlation } & Kinerja $(\times 3)$ & 1,000 & .516 \\
\hline & Kompetensi ( $\times 1)$ & .516 & 1,000 \\
\hline \multirow[t]{2}{*}{ Sig. (1-tailed) } & Kinerja $(\times 3)$ & & .000 \\
\hline & Kompetensi ( $\times 1)$ &, 000 & \\
\hline \multirow[t]{2}{*}{$\mathbf{N}$} & Kinerja (X3) & 55 & 55 \\
\hline & Kompetensi ( $\times 1)$ & 55 & 55 \\
\hline
\end{tabular}

Tabel 3.

Korelasi antara variabel kinerja(X3) dan kompetensi (X1)

\begin{tabular}{|c|c|c|c|c|c|c|}
\hline & & & ANOVA $^{a}$ & & & \\
\hline Model & & Sum of Squares & df & Mean Square & $\mathrm{F}$ & Sig. \\
\hline \multirow[t]{3}{*}{1} & Regression & 3570,633 & 1 & 3570,633 & 19,185 &, $000^{\mathrm{b}}$ \\
\hline & Residual & 9864,204 & 53 & 186,117 & & \\
\hline & Total & 13434,836 & 54 & & & \\
\hline \multicolumn{7}{|c|}{ a. Dependent Variable: Kinerja (X3) } \\
\hline \multicolumn{7}{|c|}{ b. Predictors: (Constant), Kompetensi (X1) } \\
\hline
\end{tabular}

Tabel 4.

Hasil uji statistik Anova variabel kinerja (X3) dan kompetensi (X1)

\begin{tabular}{|c|c|c|c|c|c|c|c|c|c|}
\hline \multicolumn{10}{|c|}{ Coefficients $^{a}$} \\
\hline \multirow{2}{*}{\multicolumn{2}{|c|}{ Model }} & \multicolumn{2}{|c|}{$\begin{array}{l}\text { Unstandardized } \\
\text { Coefficients }\end{array}$} & \multirow{2}{*}{$\begin{array}{c}\text { Standardized } \\
\text { Coefficients } \\
\text { Beta }\end{array}$} & \multirow[b]{2}{*}{$\mathrm{t}$} & \multirow[b]{2}{*}{ Sig. } & \multicolumn{3}{|c|}{ Correlations } \\
\hline & & $\mathrm{B}$ & Std. Error & & & & $\begin{array}{l}\text { Zero- } \\
\text { order }\end{array}$ & Partial & Part \\
\hline 1 & (Constant) & 62,504 & 13,041 & & 4,793 &, 000 & & & \\
\hline & $\begin{array}{l}\text { Kompetensi } \\
\text { (X1) }\end{array}$ & ,390 &, 089 &, 516 & 4,380 &, 000 &, 516 &, 516 &, 516 \\
\hline
\end{tabular}

\section{Tabel 5.}

Koefisien hasil uji statistik variabel dependent kinerja (X3) dan kompetensi (X1)

Dari hasil perhitungan diperoleh nilai koefisien jalur sebesar 0,516 dan nilai $t_{\text {hitung }}$ sebesar 4,380. Hal ini menunjukkan bahwa kompetensi guru berpengaruh langsung positif terhadap kinerja guru. 


\section{2) Pengaruh Implementasi Kurikulum Asing terhadap Kinerja Guru}

Setelah dilakukan uji uji normalitas variabel (X3) kinerja guru atas (X2) (implementasi kurikulum asing) di Sekolah Internasional Jakarta Utara, maka dilakukan uji statistik dengan menggunakan Statistical Package for Social Sciences (SPSS) dan uji reliabilitas, maka diperoleh hasil sebagaimana table berikut berikut ini :

\begin{tabular}{|l|r|r|r|}
\hline \multicolumn{5}{|c|}{ Descriptive Statistics } \\
& Mean & Std. Deviation & N \\
\hline Kinerja $(\times 3)$ & 119,0545 & 15,77318 & 55 \\
\hline Implementasi Kurikulum $(\times 2)$ & 116,3818 & 13,92106 & 55 \\
\hline
\end{tabular}

\section{Tabel 6.}

Deskripsi hasil uji statistik variabel dependent kinerja guru (X3) dan implementasi kurikulum asing (X2)

\begin{tabular}{|c|c|c|c|c|c|c|c|c|}
\hline \multirow[b]{3}{*}{ Model } & \multirow[b]{3}{*}{$\mathrm{R}$} & \multicolumn{7}{|c|}{ Model Summaryb } \\
\hline & & \multirow[b]{2}{*}{ R Square } & \multirow[b]{2}{*}{$\begin{array}{c}\text { Adjusted R } \\
\text { Square }\end{array}$} & \multirow[b]{2}{*}{$\begin{array}{l}\text { Std. Error of the } \\
\text { Estimate }\end{array}$} & \multirow[b]{2}{*}{$\begin{array}{l}\text { R Square } \\
\text { Change }\end{array}$} & \multicolumn{3}{|c|}{ Change Statistics } \\
\hline & & & & & & F Change & df1 & $\mathrm{df} 2$ \\
\hline 1 &, $795^{a}$ & ,632 &, 625 & 9,65570 &, 632 & 91,100 & & \\
\hline \multicolumn{9}{|c|}{ a. Predictors: (Constant), Implementasi Kurikulum (X2) } \\
\hline
\end{tabular}

Tabel 7.

Model Summary variabel kinerja guru (X3) dan implementasi kurikulum asing (X2)

\begin{tabular}{|c|c|c|c|c|c|c|c|c|c|}
\hline \multicolumn{10}{|c|}{ Koefficients ${ }^{a}$} \\
\hline & & \multicolumn{2}{|c|}{$\begin{array}{l}\text { Unstandardized } \\
\text { Coefficients }\end{array}$} & \multirow[t]{2}{*}{$\begin{array}{c}\text { Standardiz } \\
\text { ed } \\
\text { Coefficient } \\
\text { s } \\
\text { Beta } \\
\end{array}$} & \multirow[b]{2}{*}{$\mathrm{t}$} & \multirow[b]{2}{*}{ Sig. } & \multicolumn{3}{|c|}{ Correlations } \\
\hline \multicolumn{2}{|c|}{ Model } & $\mathrm{B}$ & Std. Error & & & & Zero-order & Partial & Part \\
\hline \multirow[t]{2}{*}{1} & (Constant) & 14,207 & 11,062 & & 1,284 & ,205 & & & \\
\hline & $\begin{array}{l}\text { Implementasi } \\
\text { Kurikulum }(\mathrm{X} 2)\end{array}$ & ,901 &, 094 & ,795 & 9,545 &, 000 & ,795 & ,795 & ,795 \\
\hline & pendent Variable & $a(X 3)$ & & & & & & & \\
\hline
\end{tabular}

Tabel 8.

Koefisien hasil uji statistik variabel dependent kinerja guru (X3) dan implementasi kurikulum asing (X2) 


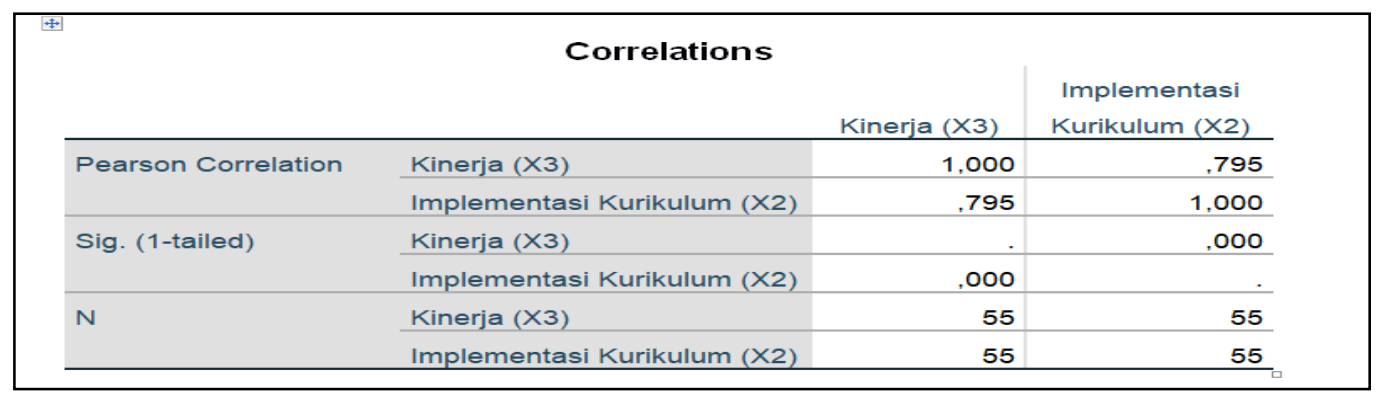

Tabel 9.

Korelasi antara variabel kinerja guru (X3) dan implementasi kurikulum asing (X2)

\begin{tabular}{|c|c|c|c|c|c|c|}
\hline \multicolumn{7}{|c|}{ ANOVA $^{a}$} \\
\hline Model & & Sum of Squares & df & Mean Square & $\mathrm{F}$ & Sig. \\
\hline \multirow[t]{3}{*}{1} & Regression & 8493,511 & 1 & 8493,511 & 91,100 &, $000^{\mathrm{b}}$ \\
\hline & Residual & 4941,325 & 53 & 93,233 & & \\
\hline & Total & 13434,836 & 54 & & & \\
\hline \multicolumn{7}{|c|}{ a. Dependent Variable: Kinerja (X3) } \\
\hline \multicolumn{7}{|c|}{ b. Predictors: (Constant), Implementasi Kurikulum (X2) } \\
\hline
\end{tabular}

Tabel 10.

Hasil uji statistik Anova variabel kinerja guru (X3) dan implementasi kurikulum asing (X2)

Dari hasil perhitungan diperoleh nilai koefisien jalur sebesar 0,795 dan nilai thitung sebesar 9,545. Hal ini menunjukkan bahwa implementasi kurikulum asing berpengaruh langsung positif terhadap kinerja guru.

\section{3) Pengaruh Kompetensi Guru terhadap Implementasi Kurikulum Asing}

Setelah dilakukan uji normalitas variable (X1) kompetensi guru terhadap variable (X2) implementasi kurikulum asing di Sekolah Internasional Jakarta Utara, maka dilakukan uji statistik dengan menggunakan Statistical Package for Social Sciences (SPSS) dan uji reliabilitas, maka diperoleh hasil sebagaimana table berikut berikut ini : 
62 TADBIR : Jurnal Studi Manajemen Pendidikan, Vol. 4, No. 1, Mei 2020

\begin{tabular}{|l|l|l|l|}
\hline \multicolumn{4}{c|}{ Descriptive Statistics } \\
& Mean & Std. Deviation & N \\
\hline Kompetensi (X1) & 144,8727 & 20,83183 & 55 \\
\hline Implementasi Kurikulum (X2) & 116,3818 & 13,92106 & 55 \\
\hline
\end{tabular}

Tabel 11.

Deskripsi hasil uji statistik variabel kompetensi guru (X1) dan implementasi kurikulum asing (X2)

\begin{tabular}{|c|c|c|c|c|c|c|c|c|}
\hline \multirow[b]{3}{*}{ Model } & \multirow[b]{3}{*}{$\mathrm{R}$} & \multicolumn{6}{|c|}{ Model Summaryb } & \\
\hline & & \multirow[b]{2}{*}{$\mathrm{R}$ Square } & \multirow[b]{2}{*}{$\begin{array}{l}\text { Adjusted R } \\
\text { Square }\end{array}$} & \multirow[b]{2}{*}{$\begin{array}{l}\text { Std. Error of the } \\
\text { Estimate }\end{array}$} & \multirow[b]{2}{*}{$\begin{array}{l}\text { R Square } \\
\text { Change }\end{array}$} & \multicolumn{3}{|c|}{ Change Statistics } \\
\hline & & & & & & F Change & df1 & $\mathrm{df2}$ \\
\hline 1 & $.528^{\mathrm{s}}$ &, 279 &, 266 & 17,85145 &, 279 & 20,536 & 1 & \\
\hline $\begin{array}{l}\text { a. Prec } \\
\text { b. Dep }\end{array}$ & $\begin{array}{l}\text { Constant, } \\
\text { Variable: }\end{array}$ & Implementa & urikulum (X2) & & & & & \\
\hline
\end{tabular}

Tabel 12.

Model summary hasil uji statistik variabel kompetensi guru (X1) dan implementasi kurikulum asing (X2)

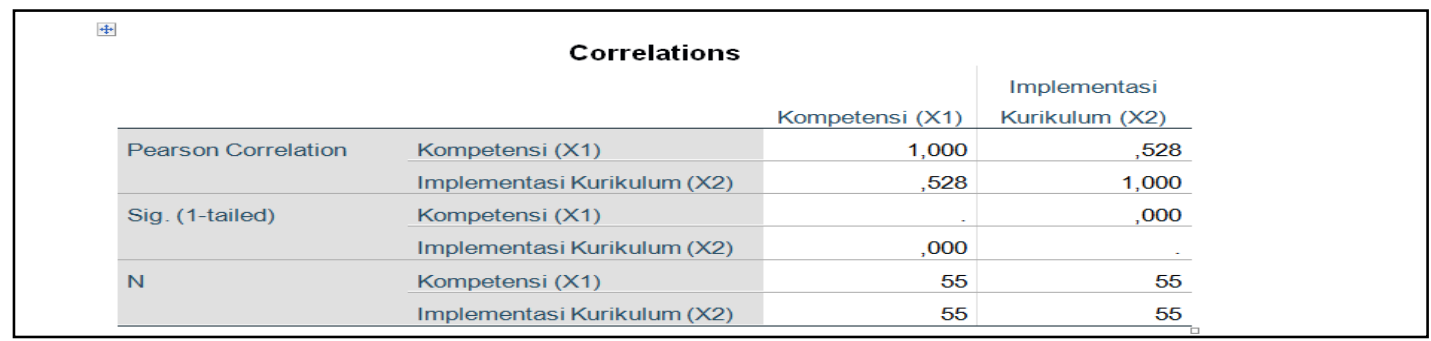

\section{Tabel 13.}

Korelasi antara variabel kompetensi guru (X1) dan implementasi kurikulum asing (X2)

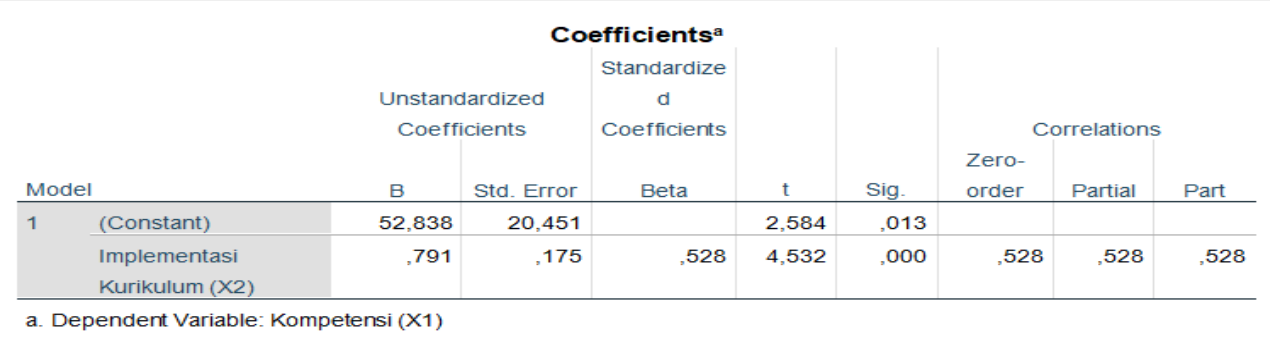

Tabel 14.

Koefisien hasil uji statistik variabel kompetensi guru (X1) dan implementasi kurikulum asing (X2) 
Dari hasil perhitungan diperoleh nilai koefisien jalur sebesar 0,528 dan nilai t-hitung sebesar 4,532. Hal ini menunjukkan bahwa kompetensi guru berpengaruh langsung positif terhadap implementasi kurikulum asing.

\section{Kesimpulan}

Berdasarkan hasil pengujian hipotesis dapat disimpulkan bahwa kompetensi guru berpengaruh langsung terhadap kinerja guru. Begitu juga dengan implementasi kurikulum asing berpengaruh positif terhadap kinerja guru. Kompetensi guru juga berpengaruh positif terhadap implementasi kurikulum asing. Dari penelitian ini dapat diambil kesimpulan bahwa kompetensi guru merupakan indikator utama dalam menjalankan kurikulum asing di sekolah Internasional Jakarta Utara, dengan demikian kinerja guru yang memiliki kompetensi dalam melaksanakan kurikulum asing menjadi urgent untuk dilakukan peningkatan oleh sekolah Internasional Jakarta Utara. Untuk meningkatkan kompetensi guru dapat dilakukn dengan in job training dan out job training.

\section{Daftar Pustaka}

Adeyemi, T. O. (2010). Principals leadership styles and teachers job performance in senior secondary schools in Ondo State, Nigeria. International Journal of Educational Administration and Policy Studies, 2(6), 83-91.

Amin, M., Sugiatno, S., \& Fathurrochman, I. (2019). Pengembangan Keilmuan Program Studi Manajemen Pendidikan Islam Tinjauan Futurologi Pendidikan dan Pengembangan Kurikulum. Tadbir: Jurnal Studi Manajemen Pendidikan, 3(2), 199-225.

Cambridge Assessment International Education. (2019).

Colquitt, J., Lepine, J. A., Wesson, M. J., \& Gellatly, I. R. (2011). Organizational behavior: Improving performance and commitment in the workplace (Vol. 375). New York, NY: McGraw-Hill Irwin.

Elisabeth, M. (2014). Implementasi Kurikulum Internasional Cambridge dan Dampaknya terhadap Pengelolaan Pembelajaran Biologi: Studi Kasus di Saint John's Catholic School Semarang (Doctoral dissertation, Universitas Negeri Semarang).

Fathurrochman, I. (2017). Pengembangan Kompetensi Pegawai Aparatur Sipil Negara (ASN) Sekolah Tinggi Agama Islam Negeri (STAIN) Curup Melalui Metode Pendidikan Dan Pelatihan. Manajer Pendidikan, 11(2).

Fathurrochman, I. (2020). Pendidikan Sebagai Media Integrasi Agama dan Sains Dalam Era Revolusi Industri 4.0. Jurnal Literasiologi, 3(1).

Heriswanto, H. (2018). Pengaruh kompetensi guru terhadap kinerja guru SMPN 
Lambuya Kab. Konawe melalui motivasi kerja sebagai variabel intervening. Aksara Public, 2(3), 136-152.

Keputusan Menteri Pendidikan Nasional Nomor 045/U/2002.

Kurniawan,A.B.H. (2018). Implementasi kurikulum integrasi: kurikulum Cambridge dan kurikulum 2013 Matematika kelas VIII di MTs Bilingual Muslimat NU Pucang Sidoarjo (Doctoral dissertation, UIN Sunan Ampel Surabaya).

Moeheriono, P. K. B. K. (2009). Competency Based Human Resource Management. Bogor, Galia Indonesia.

Olaleye, F. O. (2013). Improving teacher performance competency through effective human resource practices in Ekiti State secondary schools. Singaporean Journal of Business, Economics and Management Studies, 51(1113), 1-8.

Payong, M. R. (2011). Sertifikasi profesi guru: Konsep dasar, problematika, dan implementasinya. Indeks.

Peraturan Pemerintah No.19 Tahun 2005 tentang Standar Nasional Pendidikan.

Prasetyo, K. W. (2018). Implementasi Kurikulum Cambridge dalam Pembelajaran di SD Hj Isriati Baiturrahman 1 Semarang (Doctoral dissertation, UNNES).

Retnawati, H. (2015). Hambatan guru matematika sekolah menengah pertama dalam menerapkan kurikulum baru. Jurnal Cakrawala Pendidikan, 34(3).

Ristianti, D. H. (2018). Konseling Islami Untuk Meningkatkan Efikasi Diri Pasien HIV/AIDS. Indonesian Journal of Educational Counseling, 2(1), 113-130.

Ristianti, D. H. Putrajaya, G. Fathurrochman, I. (2020). Organizational behavior management through group counseling discussions as a radicalism preventive effort. Jurnal Konseling dan Pendidikan, 8(1), 21-35

Rojabiyati Laili, D. W. I. (2019). Implementasi Kurikulum Cambridge Pada Sistem Pembelajaran di MI Muslimat NU Pucang Sidoarjo. Inspirasi Manajemen Pendidikan, 7(3).

Simanjuntak Payaman, J. (2005). Manajemen dan Evaluasi Kinerja. Jakarta: Lembaga Penerbit Fakultas Ekonomi Universitas Indonesia.

Spencer, M. L., \& Spencer, M. S. (1993). Competence at Work: Models for Superrior Performance, John Wily \& Son. Inc. New York, USA.

Sriwidodo, U., \& Haryanto, A. B. (2010). Pengaruh kompetensi, motivasi, 
komunikasi dan kesejahteraan Terhadap kinerja pegawaidinas pendidikan. Jurnal Manajemen Sumber Daya Manusia, 4(1), 47-57.

Taiyeb, A. M., \& Sekarsari, A. (2014). Pengembangan Lembar Kegiatan Siswa (LKS) Biologi yang Terintegrasi Kurikulum Cambridge untuk SMA Kelas XI Semester II. bionature, 15(1).

Undang-Undang Republik Indonesia No.14 Tahun 2005 Tentang Guru dan Dosen. Undang-Undang Nomor 20 Tahun 2003 tentang Sistem Pendidikan Nasional. Wibowo, H. (2007). Manajemen Kinerja, Jakarta: PT. Raja Grafindo Persada.

Yanto, M., \& Fathurrochman, I. (2019). Manajemen kebijakan kepala madrasah dalam meningkatkan mutu pendidikan. Jurnal Konseling dan Pendidikan, 7(3), 123-130. 
66 | TADBIR : Jurnal Studi Manajemen Pendidikan, Vol. 4, No. 1, Mei 2020

This page belongs to the TADBIR : Jurnal Studi Manajemen Pendidikan

TADBIR : Jurnal Studi Manajemen Pendidikan vol. 4 , no. 1, Mei 2020

IAIN Curup - Bengkulu | p-ISSN 2580-3581; e-ISSN 2580-5037 